\title{
Efficacy of Photobiomodulation and Metformin on Diabetic Cell Line of Human Periodontal Ligament Stem Cells through Keap1/Nrf2/Ho-1 Pathway
}

\author{
Latifa Mohamed Abdelgawad*1, Manar Mohy Abd El-hamed², \\ Dina Sabry ${ }^{3}$, Marwa Abdelgwad ${ }^{4}$,
}

\begin{abstract}
Background: Diabetes mellitus (DM) is a metabolic disorder resulting from hyperglycemia. Hyperglycemia contributes to oxidative stress, and the release of advanced glycation end products (AGEs) further promotes disease pathogenesis. Uncontrolled diabetes reflects great oral complications and affects human oral health. So, the present study aimed to assess the effects of photobiomodulation therapy (PBMT) and Metformin on proliferation and viability of human periodontal ligament stem cells (HPDLSCs) cultured in high glucose medium.

Methods: HPDLSCs were collected, isolated, and characterized and then divided into eight groups. Addition of extra glucose to diabetic groups 24 hours before cell irradiations. Metformin was added to half of the diabetic groups. Cells were irradiated with $808 \mathrm{~nm}$ diode laser 24, 48 hours. Cell viability was analyzed with MTT assay 24 hours post-irradiation to detect cell viability in each group. Real-time (PCR) was used to evaluate gene expression of Nrf2, Keapl, PIK3, and HO-1 and the effect of PBMT on Keapl/Nrf2/Ho-1 Pathway. ELISA reader was used to evaluating cell viability through (ROS, TNF- $\alpha, \mathrm{IL}-10)$ protein levels after cell irradiation.

Results: Photobiomodulation at 1,2, and $3 \mathrm{~J} / \mathrm{cm} 2$ combined with metformin significantly promoted diabetic cell lines of HPDLSCs viability (in MTT assay and ELISA reader of ROS, TNF- $\alpha$, IL-10 results) and gene expression of Nrf2, Keapl, PIK3, and HO-1 levels ( $\mathrm{p}<0.05)$.

Conclusions: photobiomodulation with $3 \mathrm{~J} / \mathrm{cm}^{2}$ combined with metformin enhanced proliferation and viability of diabetic cell lines of HPDLSCs and thus could improve differentiation and function of diabetic cell lines of HPDLSCs with minimum side effects.
\end{abstract}

Keywords: Diabetes Mellitus, Metformin, Periodontal Ligament Stem Cells, Photobiomodulation.

\section{Introduction}

Diabetes is caused by absolute insulin deficiency due to autoimmune destruction of insulin secreting pancreatic -cells (type 1 diabetes) or by relative insulin deficiency due to decreased insulin sensitivity, usually observed in overweight individuals (type 2 diabetes). In both types of the disease, an inadequate mass of functional cells is the major determinant for the onset of hyperglycemia and development of overt disease $(1,2)$.

Chronic uncontrolled diabetes reflects serious systemic and oral complications of patients $(3,4)$. Several soft tissue lesions associated with uncontrolled diabetes commonly appear in the oral cavity like stomatitis, geographic tongue, benign migratory glossitis, fissured tongue, 
traumatic ulcer, lichen planus, and angular cheilitis. Salivary gland dysfunction and dry mouth increase susceptibility to caries and tooth deterioration (3-4). All these complications decrease response to infection due to microvascular changes, salivary hyperglycemia and gingival crevicular fluid $(5,6)$.

Incomplete wound healing has been observed as one of the most common complications of DM since diabetic wound associated with poor neovascularization, impaired angiogenesis, compromised collagen matrixes formation and reduced growth factors $(7,8)$.

Dental stem cells have been evaluated as reliable candidates in tissue regeneration, primarily as they can be obtained from unnecessary organs, such as the third molars, unlike other sources of mesenchymal stem cell (MSC) (as the adipose tissue or bone marrow), which is a comprehensibly complicated harvesting process for patients $(9,10)$. Periodontal ligament (PDL) tissues isolated from the middle third of the root surface of the extracted tooth. Subsequently, PDLs were used for its proven capability of tissue regeneration as it is rich in periodontal stem cells, which can be easily isolated and cultured in vitro for future use in vivo or in tissue banking. Several studies have isolated and used dental stem cells for treatment of diabetic wound $(11,12)$.

Photobiomodulation therapy (PBMT) is a technique that is based on the use of low- level laser (LLL) light or light emitting diodes (LEDs) to initiate therapeutic cellular effects and is used to treat many health-related conditions, including inflammation and chronic wounds. It is also used for activation of the immune system and production of growth factors. The technique involves the use of visible red and near infrared light and its effects are exhibited by inducing a photochemical reaction within the cells $(13,14)$.

Recent studies explain the effect of LLLT on Keapl/Nrf2/Ho-1 pathway which recognized as a cellular defense mechanism against oxidative stresses, xenobiotic stresses, and prevention of vascular inflammation $(15,16)$. Previous Studies recommend the use of LLLT in combined with
MSCs for better cell proliferation and differentiation $(17,18)$.

Tumor necrosis factor (TNF- $\alpha$ ) enhances the inflammation process and has an impact on angiogenesis and destructive processes (19). ROS mediate apoptosis and play a critical role in early diabetic complications (20). IL-10 plays an important as an anti-inflammatory cytokine (21). The aim of the present study focuses on the effect of photobiomodulation and metformin on HPDLSCs proliferation and viability when cultured in high glucose medium.

\section{Materials and Methods}

\section{Ethics approval}

The research related to human use has been complied with all the relevant national regulations, institutional policies and in accordance the tenets of the Helsinki Declaration, and the protocol approved by the ethics committee of National Institute of Laser Enhanced Science (NILES, REC), Cairo University, Egypt, on March 11 (identification number code 019027). All procedures were performed in the Medical Biochemistry and Molecular Biology Department (tissue culture unit) of the Faculty of Medicine, Cairo University, Egypt.

\section{Human periodontal ligament stem cells (HPDLSCs) isolation and culturing}

Sound impacted third molars were collected immediately after extraction from healthy adult male patients (22-26 years) from the outpatient clinic of Cairo University and transferred into the basic medium RPMI-1640 with L-Glutamine (BioWhittaker ${ }^{\circledR}$, Lonza, USA, catalog number (cat\#) 12-702F) with $10 \%$ fetal bovine serum (LSP®, cat\#S001B-BR) and 1\% penicillin/streptomycin (Biowest ® USA, cat\# L0018-100). Under the sterile condition, working within a biohazard laminar flow hood (Thermo Fisher Scientific ${ }^{\circledR}$, USA). Teeth were washed with phosphate buffer saline (BioWhittaker ${ }^{\circledR}$, Lonza, USA cat\#: 17-516F). A sterile scalpel blade no. 15 was used to gently scrape PDL from the middle third of roots and 
finally slice them into small $(1 \mathrm{~mm})$ pieces. Then, PDL tissues were incubated into collagenase type II (Sigma Aldrich, USA) for $2 \mathrm{~h}$ at $37{ }^{\circ} \mathrm{C}$, centrifuged, filtered, and resuspended until the pellet was formed. The cell pellet was plated and cultured in a density of $15-30 \times 103$ cells $/ \mathrm{cm} 2$ in basic medium and incubated in the culture at $37{ }^{\circ} \mathrm{C}$ with $5.5 \% \mathrm{CO} 2$ and $90 \%-95 \%$ humidity. The culture medium was changed every three days until $80 \%-95 \%$ confluence of the cell was achieved (16).

\section{Characterization of HPDLSCs} Phonotypical characterization of HPDLSCs

Subsequent culture of HPDLSCs were examined under an inverted microscope (Leica ${ }^{\circledR}$, Germany) to confirm the shape of
HPDLSCs and its special characters (plastic adherence, spindle fusiform shape) of stem cells. HPDLSCs as in Figure 1, whereas HPDLSC made colonies (as a CFU cells), expanded by time to form a fusiform like cells adherent to the culture wells at day 21 of culture (12).

\section{Immunological characterization of HPDLSC}

Fluorescence-Activated Cell Sorting (FACS) analysis was used to confirm surface antigens specific to CD90 (R\&D Systems, USA; cat\#, FAB1320F-025) and specific periodontal stem cells marker as CD29 (R\&D Systems, USA cat \#FAB2405P-025) and was negative to CD 45 (R\&D Systems, USA; cat\#FAB114A), excluding hematopoietic, endothelial cells (Fig. 2).

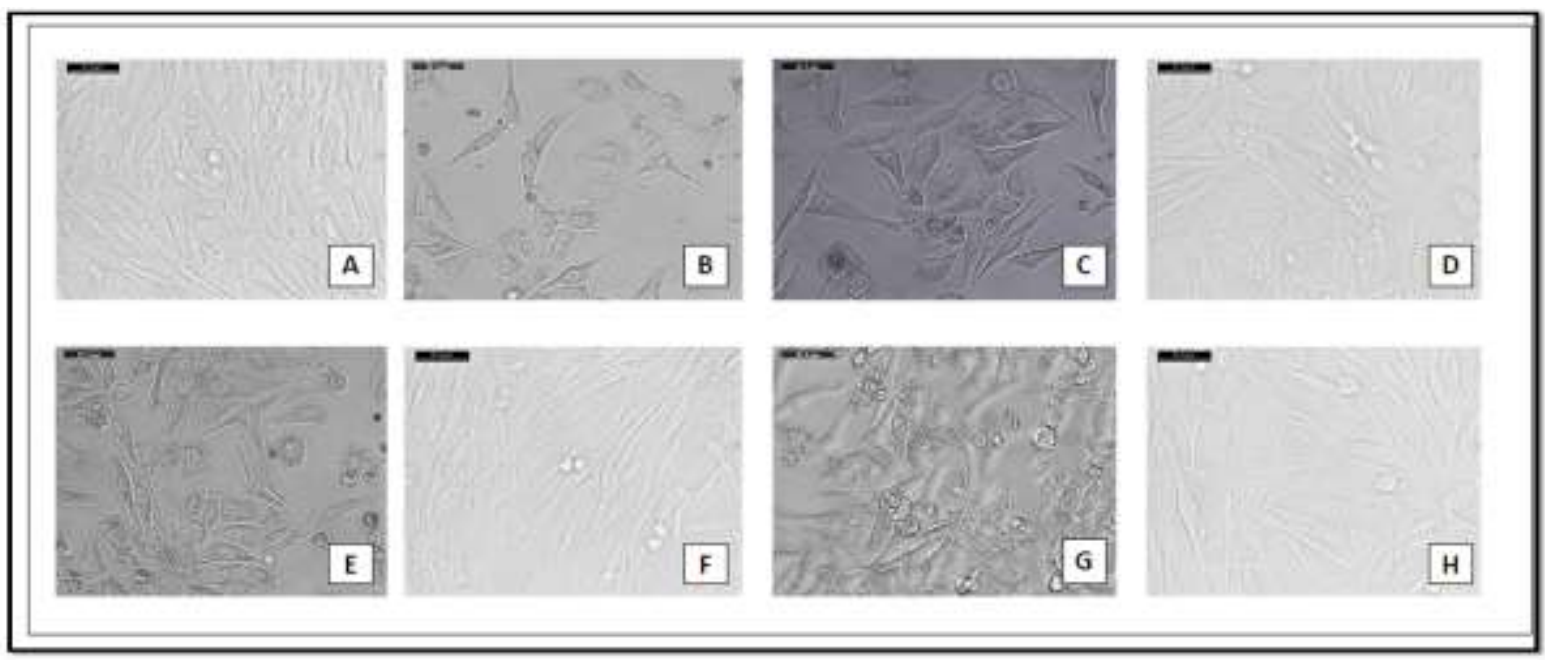

Fig. 1. A: show Group. 1 (normal cell) after 14 days, B: Group. 2 (diabetic cell) after 14 days, C: Group. 3 diabetic cells irradiated with 1 J, D: Group. 4 diabetic cells irradiated with 1 J \& metformin, E: Group. 5 diabetic cells irradiated with 2 J, F: Group. 6 diabetic cells irradiated with 2 J \& metformin, G: Group. 7 diabetic cells irradiated with 3 J, H: Group. 8 diabetic cells irradiated with 3 J \& metformin.

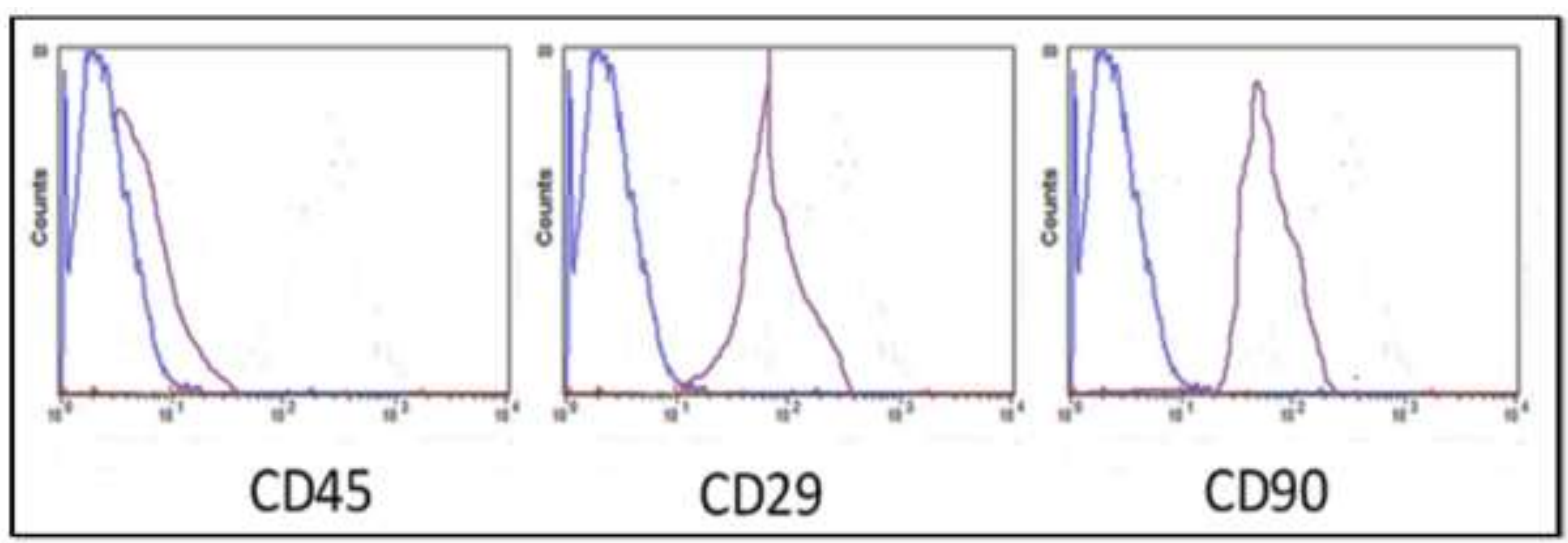

Fig. 2. Picture of FACS analysis for immunological characterization of HPDLSCs where results +ve to CD 29, CD 90 and-ve to CD 45. 


\section{Induction of DM \& applying of metformin.}

According to Ayuk 2018 (22). To create a diabetic cell model, $5 \%$ of glucose was added to research groups $24 \mathrm{~h}$ before cell irradiation. $10 \mathrm{nmol}$ of Metformin (Sigma-Aldrich Chemical Co., St. Louis, Mo, U.S.A., CAS n1115-70-4) was added for specific research groups Asghari 2017 (23).

\section{Cell culture groups}

Furthermore, 96-well tissue culture plates were equally divided into eight groups as follows when passages 3-5 of HPDLSCs were achieved and mainly passage 4: Group I ( control ), non-diabetic HPDLSCs without irradiation; group II, diabetic HPDLSCs without irradiation vitamin D alone, without irradiation; group III, diabetic HPDLSCs with laser irradiation at $1 \mathrm{~J} / \mathrm{cm} 2$; group IV, diabetic HPDLSCs cultured with metformin and laser irradiation at $1 \mathrm{~J} / \mathrm{cm} 2$; group $\mathrm{V}$, irradiation at 2 $\mathrm{J} / \mathrm{cm} 2$; group VI: metformin and laser irradiation at $2 \mathrm{~J} / \mathrm{cm} 2$; group VII: cells received $3 \mathrm{~J} / \mathrm{cm}^{2}$ laser irradiation and group VIII: HPDLSC with metformin and laserirradiated at $3 \mathrm{~J} / \mathrm{cm}^{2}$.

\section{Laser irradiation}

The culture dishes were wrapped within the dark paper sheets with a hole of a diameter corresponding to the diameter of the laser spot area of the headpiece to avoid energy dispersion. Cells were irradiated with a diode laser (SOLASE®, LAZON Medical Laser Corporation, supplied from Mcs, dental sector) in continuous wave mode parameters: 100 $\mathrm{mW}$, wavelength of $808 \mathrm{~nm}$, spot area of 0.5 $\mathrm{cm}^{2}$, and irradiation at 1,2 and $3 \mathrm{~J} / \mathrm{cm} 2$. Cells were double irradiated (at 24 and $48 \mathrm{~h}$ ) with laser probe fixed perpendicular to each plate, and irradiation was conducted in dark conditions. The cells were distributed as there were empty wells between seeded well cells to minimize the unintentional dispersion of light between wells during laser application (24).

\section{Cell viability MTT ASSAY}

Cell viability MTT assay was used in the analysis, at $24 \mathrm{~h}$ after the second laser application, which was used to assess cell metabolic activity through the number of viable cells, and absorbance was directly proportional to the number of living cells in culture. Cells were cultured in 96-well plates at a density of 1x103 cells/well, using MTT reagent (TACS, Trevigen, Gaithersburg, USA), and absorbance of the samples was monitored in an ELISA reader (Stat Fax 2200, Awareness Technologies, Florida, USA) at $450 \mathrm{~nm}(25)$.

\section{Quantitative real-time -polymerase chain reaction (RT-PCR) for genes}

Total cellular RNA for nuclear factor erythroid 2related factor 2 (Nrf2), kelch-like $\mathrm{ECH}-$ associated protein 1 (Keapl), phosphatidylinositol 3-kinase (PIK3), and heme oxygenase (HO-l) were extracted using GF-1 Nucleic Acid Extraction Kits (ViVantis ${ }^{\circledR}$ technology, USA cat\#GF-TR-050) and reverse transcribed using a complementary DNA master (SensiFAST ${ }^{\mathrm{TM}}$ One-Step Kit, USA cat\#PI-50217 V). PCR assays were conducted according to the manufacturer protocol in real-time PCR device (Step One Applied Biosystem, USA).

The human-specific PCR primers of $N r f 2$, Keapl), PIK3, and HO-I that were used are presented in Table 1. The RT reaction was followed by a real-time PCR with a SYBR Green assay performed on an Applied Biosystems (Step One System, SDS software version 2.1 and RQ Manager 1.2). GAPDH was used as an endogenous reference control gene for normalization control (26).

\section{ELISA cell viability assay}

All groups were evaluated for cell viability using ELISA reader (Dynatech MRX 5000; Dynex, Chantilly, VA) based on measure proteolytic activity of the biomarkers within the cells $48 \mathrm{~h}$ post-irradiation. Samples were analyzed for Reactive oxygen species (ROS), Tumor necrosis factor (TNF- $\alpha$ ) and interleukin-10 (IL-10) (27).

\section{Statistical analysis}

All data are presented as mean \pm standard deviation, analyzed with Student's t-test for two groups of data or one-way analysis of variance with Turkey's post hoc test for 
multiple groups of data using GraphPad Prism version 7 , where $p$ value was set as $(p<0.05)$ to indicate a statistically significant difference (28).

Table 1. Primer sequence for studied genes (NRF2, Keap1, HO-1, and PIK3).

\begin{tabular}{|c|c|c|}
\hline $\begin{array}{l}\text { Gene } \\
\text { symbol }\end{array}$ & Primer sequence from $5^{\prime}-3^{\prime}$ & $\begin{array}{l}\text { Gene bank accession } \\
\text { number }\end{array}$ \\
\hline NRF2 & $\begin{array}{l}\text { Fw - GAACTTGATGCCGTTCAGCC } \\
\text { Rv - GTCTCCACAAGGAAAGTGAATC }\end{array}$ & XM_011419592.1 \\
\hline Keap 1 & $\begin{array}{l}\text { Fw - GAGTCCAAGAAGTGCTCTAAG } \\
\text { Rv - GTCAGGATCATAGCACTCAA }\end{array}$ & XM_011433564.1 \\
\hline $\mathrm{HO}-1$ & $\begin{array}{l}\text { Fw-AGGCTGAGAATGCCGAGTTC } \\
\text { RV-TGTGGTACAAGGACGCCATC }\end{array}$ & NM_001004027.1 \\
\hline PIK3 & $\begin{array}{l}\text { Fw- GAAGCACCTGAATAGGCAAGTCG } \\
\text { Rv- GAGCATCCATGAAATCTGGTCGC }\end{array}$ & NM_006218.4 \\
\hline
\end{tabular}

\section{Results}

\section{Characterization of HPDLSCS}

Phenotypical characterization of HPDLSC was assessed under an inverted microscope (Fig. 1), whereas HPDLSC made colonies (e.g., CFU cells), expanded by time to form fusiform-like cells adherent to the culture wells at day 21 of culture.

Immunological characterization was assessed as HPDLSC were negative to CD 45 surface antigen (a), positive to CD 29 surface antigen (b), and positive to CD 90 (c) (Fig. 2).

\section{Cell viability was assessed via MTT assay}

It was measured at $24 \mathrm{~h}$. It showed that, after laser irradiation of $1 \mathrm{~J} / \mathrm{cm}^{2}, 2 \mathrm{~J} / \mathrm{cm}^{2}$ and 3
$\mathrm{J} / \mathrm{cm}^{2}$, MTT activity had a statistically significant increase at $24 \mathrm{~h}$ compared to the control group $(\mathrm{p}=0.005)$. Moreover, there was a significant difference between groups III and $\mathrm{V}(\mathrm{p}=0.04)$ with the highest values of group VII, giving the idea that laser irradiation at 3 $\mathrm{J} / \mathrm{cm}^{2}$ increases proliferation of HPDLSC compared to laser irradiation at $1 \mathrm{~J} / \mathrm{cm}^{2}$ or 2 $\mathrm{J} / \mathrm{cm}^{2}$. However, a significant value was obtained in the group with laser irradiation at 3 $\mathrm{J} / \mathrm{cm}^{2}$ and culture with metformin against metformin alone $(p<0.0001)$. These results confirmed a synergistic effect of PBMT and metformin in enhancing proliferation of HPDLSCs (Fig. 3). 


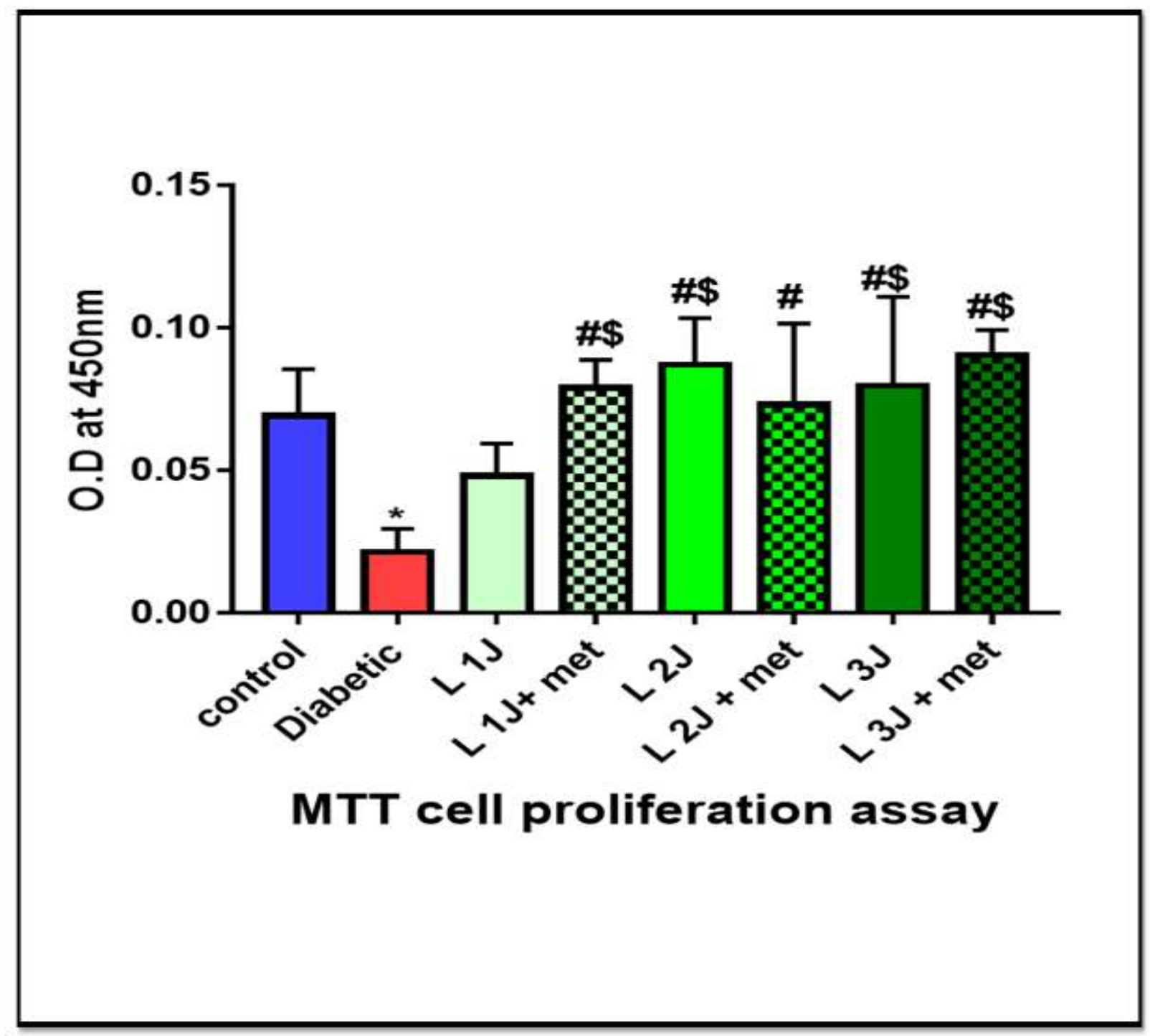

Fig. 3. Histogram of MTT assay at $24 \mathrm{~h}$ among different studied groups, showing significant between different groups of study (p value $<0.0001$ ) Data was expressed as mean $\pm \mathrm{SD}$, p-value $<0.05$ was significant.

\section{RT-PCR analysis for osteogenic genes}

\section{Nrf2 gene expression}

$N r f 2$ has antioxidant effect and increase cell proliferation and subsequently decrease rate of cell apoptosis.it showed a statistically significant difference between all groups $(\mathrm{p}<$ 0.0001 ), especially groups irradiated with 3 $\mathrm{J} / \mathrm{cm}^{2}$ than those that were irradiated at 1 $\mathrm{J} / \mathrm{cm}^{2}$ or $2 \mathrm{~J} / \mathrm{cm}^{2}$. It also showed a significant difference in group with laser irradiation at 3 $\mathrm{J} / \mathrm{cm} 2$ and culture with metformin than in group VII (laser irradiation only at $3 \mathrm{~J} / \mathrm{cm}^{2}$ ) $(\mathrm{p}<0.0001)$. Data analyzed showed that groups of metformin combined with HPDLSCs showed higher significance than groups with laser irradiation only or metformin alone (Fig. 4).

\section{Keap1 gene expression}

Similar results as those of $N r f 2$ were obtained from Keapl gene levels when measured at the end of the study $(\mathrm{p}<0.0001)$. There is a statistically significant difference between PBMT with 1,2 and $3 \mathrm{~J} / \mathrm{cm}^{2}$ ( $\mathrm{p}<0.001$ ), also a statistically significant difference between combination of PBMT at 1,2 and $3 \mathrm{~J} / \mathrm{cm}^{2}$ against diabetic group is observed $(\mathrm{p}<0.001)$ (Fig. 4). 

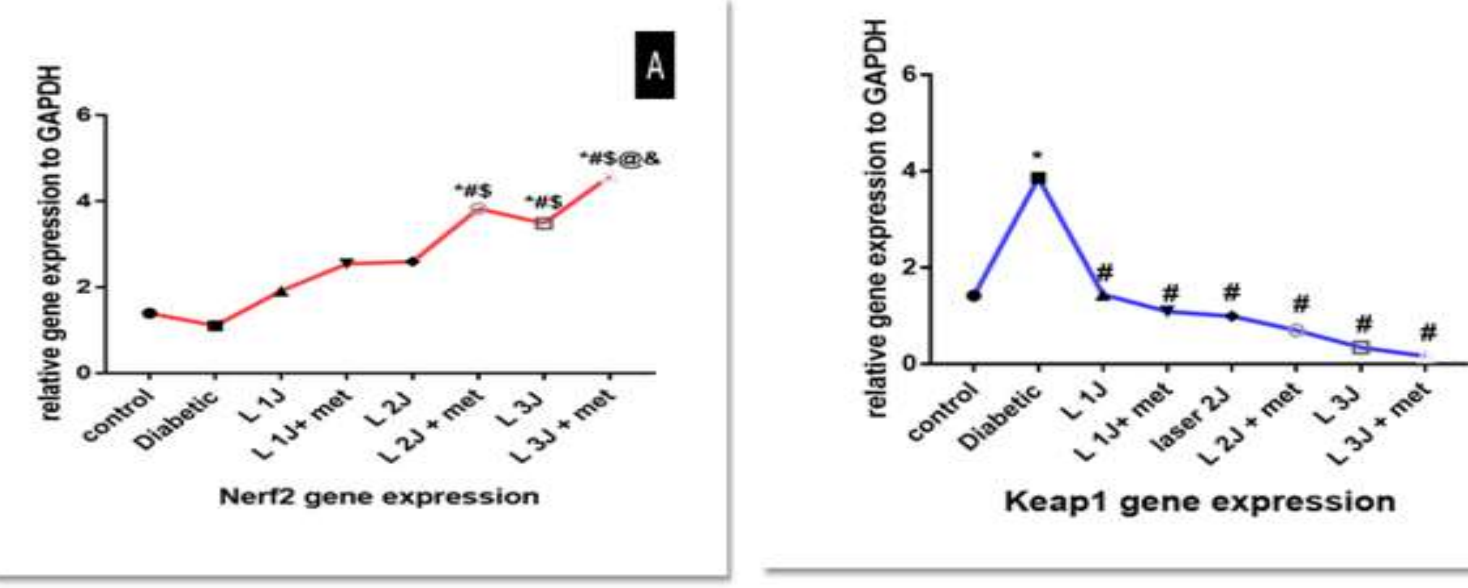

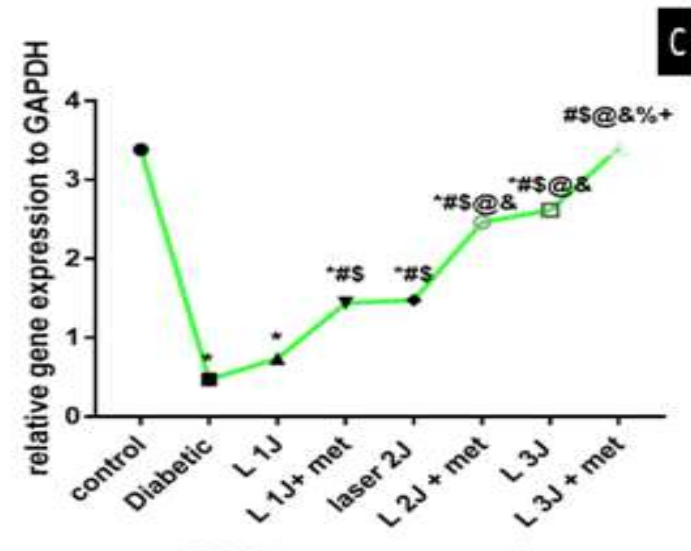

PIK3 gene expression

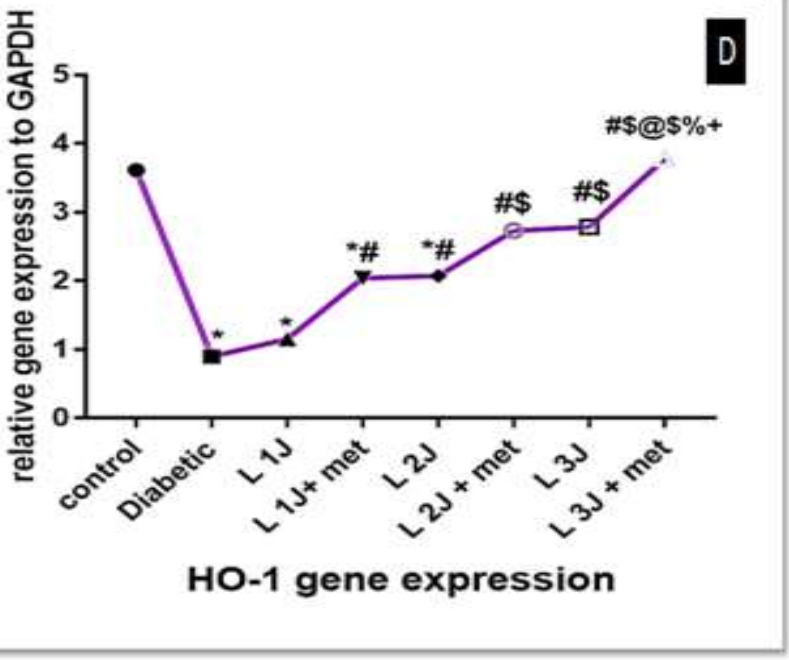

Fig. 4. A: line graph for $N r f 2$ gene expression among different groups. highest value in group laser $3 \mathrm{~J}$ and metformin, B: line graph of Keapl gene expression among studied groups with statistically significant, best results with laser $3 \mathrm{~J}$ and metformin against diabetic group, C: Line graph of PIK3 gene expression among all groups with statistically significant, best value in group irradiated with $3 \mathrm{~J}$ and metformin, D: Line graph of HO-1 gene expression among all studied groups, best value with laser $3 \mathrm{~J}$ and metformin against diabetic group. Data was expressed as mean $\pm \mathrm{SD}$, and $\mathrm{p}$-value $<0.05$ was significant.

\section{PIK3 gene expression}

There is a statistically significant difference between PBMT at $1 \mathrm{~J} / \mathrm{cm}^{2}$ with metformin, PBMT at $2 \mathrm{~J} / \mathrm{cm}^{2}$ with metformin, and PBMT at $3 \mathrm{~J} / \mathrm{cm}^{2}$ with metformin against diabetic group $(\mathrm{p}$ value $<0.0001)$.

\section{HO-1 gene expression}

$H O-1$ plays a critical role in prevention of vascular inflammation and important for cellular defense. There is a statistically significant difference between PBMT at $1 \mathrm{~J} / \mathrm{cm}^{2}$ with metformin, PBMT at $2 \mathrm{~J} / \mathrm{cm}^{2}$ with metformin, PBMT at $3 \mathrm{~J} / \mathrm{cm}^{2}$ with metformin against diabetic group ( $\mathrm{p}<0.0001)$ (Fig. 4).

\section{ELISA cell viability assay}

In comparison to the diabetic group, there is a significant decrease in ROS count. Also, there is a statistically significant difference between PBMT at $1 \mathrm{~J} / \mathrm{cm}^{2}$, PBMT at $1 \mathrm{~J} / \mathrm{cm}^{2}$ with metformin, PBMT at $2 \mathrm{~J} / \mathrm{cm}^{2}$ with metformin, PBMT at $3 \mathrm{~J} / \mathrm{cm}^{2}$, PBMT at $3 \mathrm{~J} / \mathrm{cm}^{2}$ with metformin against the diabetic group $(\mathrm{p}<$ 0.0001) (Fig. 5). 
TNF- $\alpha$ ng/ml decrease in a laserirradiated group in comparison to diabetic non - irradiated and there is a statistically significant difference between, PBMT at $1 \mathrm{~J} / \mathrm{cm}^{2}$ and metformin, PBMT at $2 \mathrm{~J} / \mathrm{cm}^{2}$, lase $2 \mathrm{~J} / \mathrm{cm}^{2}$ and metformin, laser3 and laser $3 \mathrm{~J} / \mathrm{cm}^{2}$ and metformin against a diabetic group ( $p<0.0001)$ (Fig. 5).
IL-10 $\mathrm{pg} / \mathrm{ml}$ increase in all irradiated group especially group irradiated with 3 $\mathrm{J} / \mathrm{cm}^{2}$ and There is a statistically significant difference between, PBMT $1 \mathrm{~J} / \mathrm{cm}^{2}$ with metformin, PBMT at $2 \mathrm{~J} / \mathrm{cm}^{2}$ with metformin, PBMT at $3 \mathrm{~J} / \mathrm{cm}^{2}$ with metformin against a diabetic group $(\mathrm{p}<$ 0.0001) (Fig. 5).

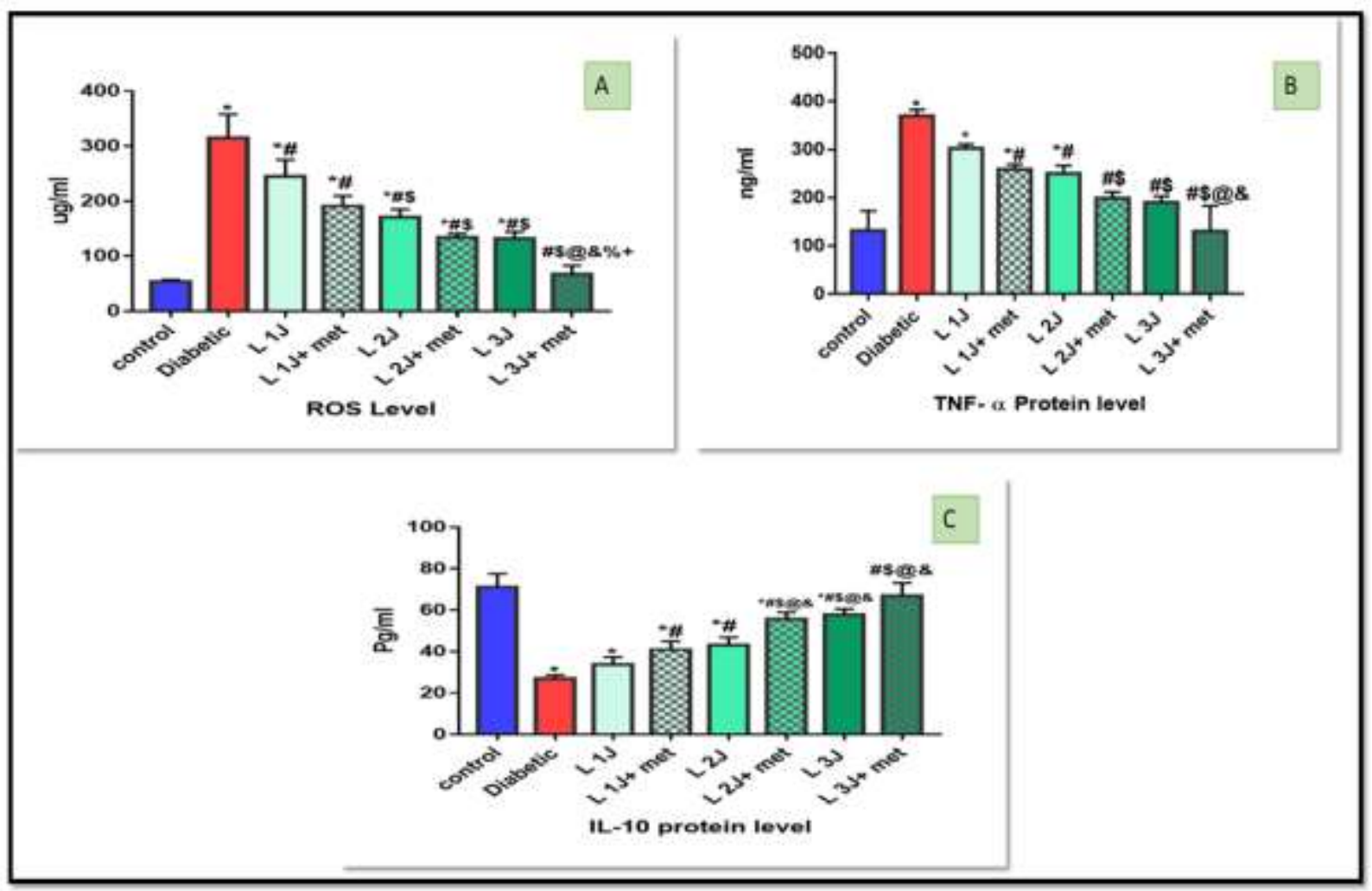

Fig. 5. A: Histogram of ROS level among all studied groups, there is a statistical significant difference between different groups of study (p value< 0.0001), B: Histogram for TNF- $\alpha$ protein level in all studied groups with statistically significant between different groups against diabetic group ( $\mathrm{p}$ value< 0.0001 ), C: Histogram for IL-10 protein level among all studied groups with statistically significant different groups of study ( $\mathrm{p}$ value $<0.0001$ ), All Data were expressed as mean $\pm \mathrm{SD}$, and $\mathrm{p}$-value $<0.05$ was significant.

\section{Discussion}

Increased blood glucose level is always associated with several dental complications. Diabetes mellitus disturb normal cellular functioning and differentiation (12). The outcome of this study based on evaluating the effect of photobiomodulation and metformin on diabetic cell lines of HPDLSCs proliferation and viability. Although previously researches approved the effect of photobiomodulation on stem cell proliferation. One cannot ignore the important methodological difference between the current study and previous investigations $(23,29)$.

In the first part of investigations MTT assay shows that PBMT has a stimulatory effect on cells proliferation, there is a statistically significant difference between PBMT at $1 \mathrm{~J} / \mathrm{cm}^{2}$, PBMT at $1 \mathrm{~J} / \mathrm{cm}^{2}$ with metformin, PBMT at 2 $\mathrm{J} / \mathrm{cm}^{2}$, PBMT at $2 \mathrm{~J} / \mathrm{cm}^{2}$ with metformin, PBMT at $3 \mathrm{~J} / \mathrm{cm}^{2}$ and PBMT at $3 \mathrm{~J} / \mathrm{cm}^{2}$ with metformin against diabetic group $(\mathrm{p}<0.0001)$. These findings were similar to previous studies as, Zare et al, (28) who approved that PBMT at $1 \mathrm{~J} / \mathrm{cm}^{2}$ 
improved the cell viability of diabetic stem cell lines. Also, Hendudari et al, (23) concluded that PBMT has great effect on cellular viability combined with $\mathrm{CM}$ in diabetic patients. While Vinck et al, (22) approved the effectiveness of PBMT with LED on fibroblast proliferation under the hyperglycemic condition.

In the second part of the investigations, RTPCR evaluated gene expression of (Nrf2, Keep 1, PIK3, HO-1) to all studied groups. Nrf2 revealed statistically significant difference between PBMT at $2 \mathrm{~J} / \mathrm{cm}^{2}$ with metformin and PBMT at $3 \mathrm{~J} / \mathrm{cm}^{2}$ with metformin against diabetic group ( $\mathrm{p}$ 0.0001). Keapl approved a statistically significant difference between PBMT at 1,2 and $3 \mathrm{~J} / \mathrm{cm}^{2}$ combined with metformin against diabetic group $(p<0.0001)$. These results agreed with those of a study by Chen et al, $(29,33)$ who reported the same result and recognize Keep 1 as a negative regulator of $N r f 2$. The $N r f 2$ - Keep 1 system also recognized as a cellular defense mechanism against oxidative and xenobiotic stresses. Also suggested as protecting against pathologies, liver toxicity, and inflammation (15, 27, 32).

PIK3 was measured in all test groups, showing high significance in group VII $\left(3 \mathrm{~J} / \mathrm{cm}^{2}\right)$ than in group $\mathrm{V}\left(2 / \mathrm{cm}^{2)}\right)$ and group III $(1 \mathrm{~J} / \mathrm{cm} 2)$. These results agreed with those of a study by Chen et al, $(22,33)$ explain the role of PIK3 in osteogenic differentiation. $\mathrm{HO}-1$ gene expression increases with photobiomodulation and show statistically significant difference between laser $1 \mathrm{~J} / \mathrm{cm}^{2}$ and metformin, laser $2 \mathrm{~J} / \mathrm{cm}^{2}$, laser $2 \mathrm{~J} / \mathrm{cm}^{2}$ and metformin, laser $3 \mathrm{~J} / \mathrm{cm}^{2}$ and laser $3 \mathrm{~J} / \mathrm{cm}^{2}$ and metformin against diabetic group $(\mathrm{p}<0.0001)$. Maines et al, (18) explained the role of $\mathrm{HO}-\mathrm{l}$ in cellular defense mechanism and against oxidative stress.

In the third part, ELISA assay used to evaluate the proteolytic activity of ROS which decreases with PBMT combined with metformin because of increased cell viability. This was also confirmed by Kelly et al, $(14,16)$, who revealed and approved the reduction of ROS in the presence of metformin in a diabetic cell.

Studies that have described TNF- $\alpha$ to decrease after PBMT of MSCs $(21,29)$ used PBMT in the cell therapy for bone regeneration.
Additionally, a study conducted by Joussen et al explained how TNF- $\alpha$ mediate apoptosis and its role in early diabetic retinopathy and other complications (19).

TNF- $\alpha$ protein level markedly decrease in group VIII (PBMT at 3J with metformin against the diabetic group which reflects the role of PBMT and metformin on cell viability. Joussen et al, $(19,21,29)$ explained how TNF- $\alpha$ mediate apoptosis and its role in early diabetic retinopathy and other complications. IL-10

$\mathrm{pg} / \mathrm{ml}$ protein level increase because of LLLT and metformin which is very important as an anti-inflammatory cytokine. Hong et al, (17) report increase its level because of the LLL application which agreed with our study.

The results of the present study indicated a synergistic effect of PBMT and metformin on improving diabetic cell lines proliferation. and viability which reflect on improve osteogenic differentiation and wound healing process with minimum side effects.

However, literature has limited data on the use of PBMT with metformin. It showed good results, such as those in this study, through the expression of $\mathrm{Nrf2}$, Keep 1, PIK3, HO-1 genes compared with irradiated groups, cultured without metformin. Such studies needed more future trials to be used in upcoming applications of cell therapy in diabetic cases.

Application of photobiomodulation and metformin, alone or in combination improve diabetic periodontal stem cell lines proliferation and viability. The combined application of $3 \mathrm{~J} / \mathrm{cm}^{2}$ of diode $808 \mathrm{~nm}$ and metformin showed a synergistic effect and a statistically more desirable outcome than application one of them alone. More investigations are needed to the evaluated effect of photobiomodulation and metformin in different glucose concentrations.

\section{Acknowledgements}

We are grateful to biochemistry and molecular biology department for their support and provide us with facilities to make this work. This research received no specific grant from any funding agency in the public, commercial, or not-for-profit sectors. 


\section{References}

1. Eliasson B, Cederholm J. The gap between guidelines and reality: Type 2 diabetes in a National Diabetes Register 1996-2003. Diabet Med. 2005;22(10):1420-6.

2. American Diabetes Association.

Classification and diagnosis of diabetes. Diabetes Care. 2015; 38(Supplement 1):S8-S16.

3. Bryant W, Green field JR, Chisholm DJ, Campbell LV. Diabetes guidelines: easier to preach than to practice?. Med J Aust. 2006;185(6):305-9.

4. Zhao GE, Hochwalt PC, Usui ML, Underwood RA, Singh PK, James GA, et al. Delayed wound healing in diabetic $(\mathrm{db} / \mathrm{db})$ mice with pseudomonas aeruginosa biofilm challenge: a model for the study of chronic wounds. Wound Repair Regen. 2010;18(5):467-77.

5. Vernillo AT. Diabetes mellitus: relevance to dental treatment. Oral Surg Oral Med Oral Pathol Oral Radiol Endo. 2001;91(3):263-70.

6. Chavez EM, Borrell LN, Taylor GW, Ship JA. a longitudinal analysis of salivary flow in control subjects and older adults with type 2 diabetes. Oral Surg Oral Med Oral Pathol Oral Radiol Endod. 2001;91(2):166-73.

7. Nwaneri C. Diabetes mellitus: a complete ancient and modern historical perspective. Webmedcentral. 2015.

8. Ginani F, Soares DM, Vasconcelos Barreto MPE, Barboza CAG. Effect of low level laser therapy on mesenchymal stem cell proliferation: a systematic review. Laser Med Sci. 2015;30(8):2189-94.

9. Zajac J, Shretha A, Patel P, Porestsky L. Principles of diabetes mellitus. Second Edition. Springer publishing; 2010.

10. Houreid $\mathrm{N}$, Abrahams $\mathrm{E} \mathrm{H}$. in vitro exposure of wounded diabetic fibroblast cells to a helium-neon laser at 5 and $16 \mathrm{~J} / \mathrm{cm}^{2}$. Photomed Laser surg. 2007;25(2):78-84.

11. Verma SK, Maheshwari S, Kumar Singh R, Kumar Chaudhari P. Laser in dentistry: an innovative tool in modern dental practice. Natl $\mathrm{J}$ Maxillofac surg. 2012;3(2):124-32.

12. Oshima M, Mizuno M, Imamura A, Ogawa M, Yasukawa M, Yamazaki H, et al. Functional tooth regeneration using a bioengineered tooth unit as a mature organ replacement regenerative therapy. PLos One. 2011;6(7):e21531.

13. Ikeda E, Morita R, Nakao K, Ishida K, Nakamura T, Takano-Yamamoto T, et al. Fully functional bioengineered tooth replacement as an oragn replacement therapy. Proc Natl Acod SCi U S A. 2009;106(32):13475-80.

14. Kelly B, Tannabill GM, Murphy MP, O'Neill LAJ. Metformin inhibits the production of reactive oxygen species from NADH: ubiquinone oxidoreductase to limit induction of interleukin-1B(IL-1B) and boosts interleukin-10 (IL-10) in lipopolysaccharide (LPS)-activated macrophages. J Biol Chem. 2015;290(33):20348-59.

15. Zorov DB, Juhaszova M, Solloll SJ. Mitochondrial Ros- induced ROS release: an update and review. Biochim Biophys Acta. 2006; 1757(5-6):509-17.

16. Konopka K, Goslinski T. Photodynamic Therapy in Dentistry. Journal of Dental Research. 2007;86(8):694-707.

17. Hong EG, Koh JH, cho YR, Kim HJ, Ma Z, $\mathrm{Yu} \mathrm{TY}$, et al. Interleukin-10 prevents dietinduced insulin resistance by attenuating macrophage and cytokine response in skeletal muscle. Diabetes. 2009;58(11):2525-35.

18. Mainess MD, Mark JA, Ewing JF. Heme oxygenase, a likely regulator of cGMP production in the brain induction in vivo oh $\mathrm{Ho}-\mathrm{l}$ compensates for depression in NO synthase activity. Mol Cell Neurosci. 1993;4(5):398-405.

19. Joussen AM, Poulaki V, Mitsiades N, Kirchhof B, Koizumi K, Döhmen S, et al. Nonsteroidal anti-inflammatory drugs prevent early diabetic retinopathy via TNF- alpha suppression. FASEB J. 2002;16(3):438-40.

20. Ayuk SM, Houreld NN, Abrahamse H. Effect of $660 \mathrm{~nm}$ visible red light on cell proliferation and viability in diabetic models in vitro under stressed conditions. Lasers Med Sci. 2018;33(5):1085-1093

21. Asghari M, Kanonisabet A, Safakhah M, Azimzadeh Z, Mostafavinia A, Taheri S, et al. the effect of combined photobiomodulation and 
metformin on open skin wound healing in a nongenetic model of type II diabetes. J Photochem Photobiol B. 2017;169:63-69.

22. Vinck EM, Cagnie BJ, Cornelissen MJ, Declercq HA, Cambier DC. Green light emitting diode irradiation enhances fibroblast growth impaired by high glucose level. Photomed laser surg. 2005;23(2):167-71.

23. Hendudari F, Bayat M, Piryaei A. Combined effects of low-level laser therapy and human bone marrow mesenchymal stem cell conditioned medium on viability of human dermal fibroblasts cultured in a high-glucose medium. Laser med sci. 2016;31(4):749-57.

24. Kaspar JW, Niture SK, Jaisual AK. Nrf2:INrf2 (Keap1) signaling in oxidative stress. Free Radic Biol Med. 2009;47(9):1304-1309.

25. Long T, Liu G, Wang Y, Chen Y, Zhang Y, Qin. TNF- $\alpha$, erectile dysfunction, and NADPH oxidase-mediated ROS generation in corpus cavernosum in high-fat diet/streptozotocininduced diabetic rats. J Sex Med. 2012;9(7):1801-14.

26. Chany Y. Quantitive data- parametric \& Non-parametric tests. Singapore Med J, 2003; 44:391-396.

27. Liu Y, Yang H, Wen Y, Li B, Zhao Y, Xing $\mathrm{J}$, et al. Nrf2 inhibits periodontal ligament stem cell apoptosis under excessive oxidative stress. Int J Mol Sci. 2017;18(5):1076.
28. Zare F, Bayat M, Aliaghaei A, Piryaei A. Photobiomodulation therapy compensate the impairments of diabetic bone marrow mesenchymal stem cells. Laser in Med Sci. 2020;35(3):547-556.

29. Ke B, Shen XD, Zhargy Y, Haofeng Ji, Gao F, Yue S. KEAP1-NRF2 complex in ischemiainduced hepatic cellular damage of mouse liver transplants. J Hepatol. 2013;59(6):1200-1207.

30. Itoh K, Wakabayashi N, Katoh Y, Ishii T, O'Connor T, Yamamoto M. Keap1 regulates both cytoplasmic-nuclear shutting and degradation of $\mathrm{Nrf} 2$ in response to electrophiles. Genes cells. 2003;8(4):379-91.

31. Yuan Z, Zhang J, Huang Y, Zhang Y, Liu $W$, Wang $G$, et al. NRF2 overexpression in mesenchymal stem cells induces stem-cell marker expression and enhances osteoblastic differentiation. Biochem Biophys Res Commun. 2017;491(1):228-235.

32. Lee JS, Yi JK, An YS, Heo YS. increased osteogenic differentiation of periodontal ligament stem cells on polydopamine film occurs via activation of integrin and PI3K signaling pathways. Cell physiol biochem. 2014;34(5):1824-34.

33. Chen H, Hung HS, Hsu ST. Low-energy laser irradiation increases endothelial gene expression possibly via PI3k signal pathway. Lasers surg Med.2008;40(1):46-54. 